\title{
Forage selection by cattle on fescue prairie in summer or winter
}

\author{
WALTER D. WILLMS AND LYLE M. RODE
}

Authors are range ecologist and ruminant nutrionist, Agriculture and Agri-Food Canada, Lethbridge Research Station, Lethbridge, Alberta, T1J 4BI.

\begin{abstract}
The rough fescue grasslands are important for livestock grazing as well as other values such as wildlife habitat, recreational opportunities, and watershed properties. The impact of livestock on these grasslands must be better understood in order to manage grazing for optimal use of the resource. A study was conducted from 1992 to 1994 on the rough fescue grassland near Stavely, Alberta, to determine forage selection by cattle in the winter and summer and the effect of canola supplementation on forage selection. Twelve 1.7-ha paddocks were stocked with 2 cows (Hereford) at 3.2 animal-units-months ha-1 in winter; canola supplements $\left(0.0,0.4,0.8\right.$, and $1.2 \mathrm{~kg} \mathrm{animal}^{-1}$ day $\left.^{-1}\right)$ were applied in a randomized complete block design. Three additional 1.7-ha paddocks were similarly stocked but grazed in the summer without canola supplements. Forage availability, utilization, and relative preference were estimated for 4 major plant species. In both winter and summer, rough fescue (Festuca campestris $\mathbf{R y d b}$.) was utilized most (P < 0.05) and Idaho fescue (Festuca idahoensis Elmer) and smooth aster (Aster laevis L.) were utilized the least. Of total forage utilized, rough fescue and Parry oat grass (Danthonia parryi Scribn.) contributed about 90 and $9 \%$, respectively, in winter and about 62 and $32 \%$, respectively, in summer. In summer, Parry oat grass was utilized in proportion to its availability. Rough fescue was the preferred species in both winter and summer. Percent forage utilization in winter was not affected by supplementation with canola. The high preference for rough fescue appeared to be determined by the accessibility of the large tufted plants to cattle. This was particularly evident in winter when access to plants was impaired by snow cover. Successful winter grazing on these grasslands is enhanced with a large proportion of rough fescue plants in the stand.
\end{abstract}

Key Words: Festuca campestris, Festuca idahoensis, Aster laevis, Danthonia parryi, species preference

Climax communities of the rough fescue grasslands are dominated by rough fescue (Festuca campestris Rydb.) in southern Alberta. Rough fescue is sensitive to grazing during the growing season (Willms et al. 1985) but tolerates grazing in winter.

The authors are indebted to Mr. Dan Murray who took responsibility for designing and fencing the paddocks, repair, and construction of complementary facilities, and the care and handling of animals. Mr. Bob Gschaid and Mr. Mike Strate collected and compiled the field data. The study was funded in part by the Alberta Agriculture and Rural Development through the Farming For the Future program. This is LRC Contribution No.3879701.

Manuscript accepted 14 Mar. 1998.
Therefore, winter grazing by livestock could be practiced both to protect the grasslands and reduce the cost of winter feeding.

The value of grasslands for winter grazing is dependent on forage availability and quality. In winter, the crude protein content and digestibility of forage are similar among species on the rough fescue grasslands (Johnston and Bezeau 1962, Bezeau and Johnston 1962). Chemical differences among herbage species are smaller after senescence than during the growing season suggesting that palatability among species might be more similar in winter than summer. Consequently, forage selection by herbivores in winter will be determined primarily by species availability in a strategy to maximize feed intake (Westoby 1974).

The effect of grazing on the plant community may be altered by supplying supplements to cattle. Supplementation with crude protein is a recommended practice for cattle on winter range (DelCurto et al. 1990) that may also lessen their forage selectivity by reducing malaise imposed by nutrient-deficient diets (Provenza 1995).

The rough fescue grasslands are important for livestock grazing as well as other values such as wildlife habitat, recreational opportunities, and watershed properties. The impact of livestock on these grasslands must be better understood in order to manage grazing for optimal use of the resource. Therefore, a study was conducted to determine forage selection by cattle grazing rough fescue grassland in the winter and summer and to evaluate the effect of supplementation with canola meal on forage selection in winter.

\section{Methods}

The study was situated on rough fescue grasslands at the Agriculture and Agri-Food Canada Range Research Substation west of Stavely, Alberta $\left(50^{\circ} 12^{\prime} \mathrm{N}, 113^{\circ} 54^{\prime} \mathrm{W}\right)$. Fifteen paddocks ( 1.7 ha each) were constructed on grassland that had been infrequently grazed during the previous 50 years and had received only light grazing pressure in any year. Rough fescue was the dominant species and the grassland was in excellent condition (Wroe et al. 1988).

\section{Grazing Animals}

A crude protein supplement, based on canola meal with mincrals to achieve a level of about $32 \%$ CP dry matter basis, was randomly allocated to 4 treatments $\left(0,0.4,0.8\right.$, and $1.2 \mathrm{~kg}$ day $^{-1}$ per animal) among 12 paddocks ( 1.7 ha each) in a randomized complete block design with 3 replications. Two pregnant Hereford cows were assigned to each paddock for a 2-month period from 1 
December to 31 January in each of 3 consecutive years. In a second experiment, 3 other paddocks were stocked with 2 Hereford cow-calf pairs in summer, between late June and early September, for a 2-month period to compare with forage selection in winter. The stocking rate averaged $3.3 \mathrm{AUM} \mathrm{ha}^{-1}$ and varied from 3.2 to $3.4 \mathrm{AUM} \mathrm{ha}^{-1}$ among years depending on cow weight. The cows were from the same herd each year and rerandomized among treatments.

During winter grazing, the cows used snow for their water supply and water was delivered to a trough when snow was unavailable. A wind barrier ( $5 \mathrm{~m}$ wide $\times 2 \mathrm{~m}$ high) was constructed from spaccd boards in each paddock to provide protection for the animals and to capture snow.

\section{Forage Selection}

Forage standing crop was determined with both a clipping and a non-destructive technique. Eight randomly distributed plots $(0.5$ $\mathrm{m}^{2}$ ) were clipped before grazing in each paddock to determine standing crop as an estimate of available forage; different plots were clipped each year. Dry matter disappearance was determined using repeated measurements of individual plants of selected species before and after grazing. The species surveyed were rough fescue (Festuca campestris Rydb.), Idaho fescue (Festuca idahoensis Elmer), Parry oat grass (Danthonia parryi Scribn.) and smooth aster (Aster laevis L.) which formed the major components of the standing crop. Two $4 \times 4 \mathrm{~m}$ grids were located in each paddock. From each grid, two $1-\mathrm{m}^{2}$ plots were randomly selected and the plants within each were mapped, numbered by species, and measured for basal area and height. Basal area and height of each grass plant, and the height of each smooth aster plant, were measured before grazing and again after grazing. In the final sample, the proportion of grazed plant area was estimated visually and the height of grazed stubble was measured. This technique could be applied to rough fescue in summer because it achieves maximum standing crop by mid-June (Stout et al. 1981) and will not regrow readily. Eighty-five percent or more of peak standing crop on the rough fescue community is attained by mid-June (Willms 1988).

Plant biomass was estimated according to Willms et al. (1980). This technique required calculating 2 regression equations describing the relationships of (1) plant weight to plant volume and (2) the distribution of biomass to plant height. A sample of 5 plants species ${ }^{-1}$ paddock $^{-1}$ year ${ }^{-1}$ was obtained at the beginning of each grazing period from the winter and summer grazed paddocks for a total of 60 and 15 plants, respectively, that encompassed a wide range of plant sizes. Their basal areas and heights were measured and their cylindrical volumes calculated. Oven dry weights were determined, regression analyses (simple and quadratic polynomials) calculated, and the best equation expressing the relationship between plant weight and volume was selected based on the significance of an improved $R^{2}$ and visually from a scatter plot. The relationship between the distribution of plant weight and height was estimated from 2 plants harvested from each species in each paddock. The plants were cut into $5 \mathrm{seg}-$ ments of equal length ( $20 \%$ of total plant height), oven dried, and weighed. The proportion of total plant weight was calculated for each segment and regression equations (simple, quadratic, and cubic polynomials) of proportion weight on proportion height were calculated. New equations were calculated in each year of the study. These equations were used to determine standing crop of grass, by species, before and after grazing. The contribution of smooth aster was determined from total plant numbers and an average plant weight determined from 10 randomly selected plants at the site. Dry matter disappearance was estimated for each species as the difference in weight before and after grazing. Indices of forage preferences were calculated from dry matter disappearance from each species as a proportion of the amount of that species on the range (Kreuger 1972).

\section{Feeding Survey in Relation to Snow Cover}

Six surveys were made of feeding behaviour in the winter of 1992/93 when snow cover was persistent and deep. At each survey, a single transect was defined across the width of each paddock. Seven observation points were established at predetermined intervals where estimates were made of snow depth, snow cover, species utilized, and proportion of grazed area. Snow depth was estimated as the average of 5 measurements. All other estimates were made visually within about a $10-\mathrm{m}$ radius.

\section{Data Analyses}

Standing crop and percent utilization were assessed among the winter-grazed paddocks using analysis of variance for a split plot design in space and time (Steel and Torrie 1980). Supplementation treatment (main effect) was evaluated with the replicate $X$ supplementation treatment interaction; species and its interaction with supplementation treatment were evaluated as the secondary effects with the species $X$ supplementation $X$ replication interaction while ycar and its intcractions with supplementation treatment and species were evaluated as the tertiary effects with the residual. Season of grazing (summer vs winter with no canola supplementation) was tested in a completely random design for the effects of grazing season, species, years, and their interactions. Although the summer grazed paddocks were not randomly distributed with the winter-grazed paddocks, they were contiguous to them and the analysis was made with the assumption that the contribution of site to experimental error was random. Indices of relative preference were statistically analysed for each test as above but only for species and its interaction with supplementation treatment or season, depending on the analyses, and year. Analysing any other main effects, or interactions of main effects without species, was meaningless and their contribution was pooled in the error term. Paired means were compared with a protected $(\mathrm{P}<0.05)$ L.S.D. (Steel and Torrie 1980).

Utilization of individual rough fescue and Parry oat grass plants were examined for the winter (no canola supplements) and summer grazed paddocks by categorizing them according to 5 levels of use: $1=0 \%, 2=>0$ to $25 \%, 3=>25$ to $50 \%, 4=>50$ to $75 \%$, and $5=>75 \%$. Comparisons between winter and summer grazing effects on the frequency distributions in each class were made for each year and for years combined, for both rough fescue and Parry oat grass, using a Chi-square test.

\section{Results}

Snow accumulation was the greatest in 1992/93 and the least in $1994 / 95$ (Table 1). Winter temperatures during the trial were also lowest in the first year. 
Table 1. Precipitation and average temperatures in December and January over 3 years in southwest Albertal.

\begin{tabular}{|c|c|c|c|c|}
\hline & \multicolumn{2}{|c|}{ Precipitation } & \multicolumn{2}{|c|}{ Temperature } \\
\hline & Dec. & $\begin{array}{r}\text { Jan. } \\
\end{array}$ & Dec. & Jan. \\
\hline $1992 / 93$ & 48.0 & 8.1 & -5.4 & -10.6 \\
\hline 1993/94 & 11.5 & 17.4 & -0.7 & -6.0 \\
\hline $1994 / 95$ & 11.0 & 5.4 & -4.0 & -5.7 \\
\hline
\end{tabular}

${ }^{1}$ Average from Pincher Creek and Claresholm (from Alberta Agriculture, Food, and Rural Development. 1994. Alberta Agricultural Weather Sumutary, Vol.8, Issue 35; and Alberta Agricultural , Food, and Rural Development. 1995. Alberta Agricultural Weather Summary, Vol.9, Issue 1).

\section{Forage Selection}

On the winter-grazed paddocks, rough fescue and Parry oat grass contributed about 68 and $25 \%$, respectively, to available standing crop (Table 2 ). There was significantly $(\mathrm{P}<0.05)$ less rough fescue standing crop in the paddocks of the $1.2 \mathrm{~kg}^{\text {day }}{ }^{-1}$ canola meal supplementation treatment than in the other treatments of the winter-grazed paddocks (Table 2). Standing crop of total biomass was similar among the winter-grazed treatments and between the winter (no supplementation) and summer-grazed treatments (Table 2). Standing crop varied among years $(\mathrm{P}<$ 0.05 ) and over the study period was estimated to be $2,444,3,409$, and $3,044 \mathrm{~kg} \mathrm{ha}^{-1}$ in 1992,1993, and 1994, respectively.

Percent forage utilization was not affected by supplementation on the winter grazed paddocks $(P>0.05$ ). Percent utilization was greater in the summer-grazed paddocks (49\%) than in the wintergrazed paddocks without supplementation (29\%). In both winter and summer, the proportion of use on rough fescue was the greatest $(\mathrm{P}<0.05)$ while the proportion of use on Idaho fescue and smooth aster was the least (Table 3). Of total forage utilized, rough fescue and Parry oat grass contributed about 90 and $9 \%$ (Tables 2 and 3), respectively, in winter and about 62 and 32\%, respectively, in summer.

In winter, the index of relative preference was greatest $(\mathrm{P}<$ $0.05)$ for rough fescue and tended to be similar $(P>0.05)$ among Parry oat grass, Idaho fescue, and smooth aster (Table 4). However, the preference for Parry oat grass increased $(P<0.05)$ from 1992 to 1994 while those of rough fescue tended to decrease $(P>0.05)$. Indices of relative preference between winter and summer were similar $(P>0.05)$ for rough fescue but increased in the summer $(P<0.05)$ for Parry oat grass and Idaho fescue (Table 4).
Table 2. Average standing crops over 3 consecutive years, estimated at the beginning of each grazing trial, of important forage species on rough fescue grassland in paddocks grazed by cattle in winter (supplemented with different rates of canola meal) or summer.

\begin{tabular}{|c|c|c|c|c|}
\hline Grazing treatment: & $\begin{array}{c}\text { Parry } \\
\text { oatgrass }\end{array}$ & $\begin{array}{l}\text { Idaho } \\
\text { fescue }\end{array}$ & $\begin{array}{l}\text { Rough } \\
\text { fescue }\end{array}$ & $\begin{array}{c}\text { Smooth } \\
\text { aster }\end{array}$ \\
\hline \multicolumn{5}{|c|}{ Winter } \\
\hline \multicolumn{5}{|c|}{ Canola supplementation } \\
\hline$\left(\mathrm{kg} \mathrm{day}^{-1}\right)$ & $\ldots \ldots$ & $-(\mathrm{kg} \mathrm{t}$ & - & $\cdots$ \\
\hline 1.2 & 1,173 & 300 & 1,467 & 104 \\
\hline 0.8 & 550 & 142 & 2,148 & 55 \\
\hline 0.4 & 630 & 100 & 1,946 & 68 \\
\hline 0.0 & 600 & 64 & 2,329 & 26 \\
\hline
\end{tabular}

${ }^{1}$ LSD $(P=0.05):$ species $\times$ canola supplementation effects $=498$

Surmmer

${ }^{1}$ LSD $(P=0.05)$ : species $X$ season summer vs winter with no supplements) effects $=279$

'LSD's were calculated only for significant $(P<0.05)$ factors as determined by ANOVA's of canola supplementation effects in winter and of the seasonal (summer vs winter with no supplements) effects.

The percent frequency of utilization classes for rough fescue plants tended to be bimodal (Table 5). In winter, the peak frequencies occurred at $0 \%$ and between 25 to $75 \%$ utilization while in summer they occurred at $0 \%$ and greater than $50 \%$ utilization. Most Parry oat grass plants were ungrazed in winter, but their utilization followed a similar bimodal frequency distribution as rough fescue in summer.

\section{Feeding Survey in Relation to Snow Cover}

On the plots where grazing was observed, rough fescue was the most frequently utilized species at any survey date in the first winter and when from 40 to $92 \%$ of the plots showed evidence of grazing (Table 6). Observed grazing was influenced by grazing rate and snow cover. Wheatgrass (Agropyron spp.), timothy (Phleum pratense L.), smooth or northern awnless brome (Bromus inermis Leyss.; B. pumpellianus Scribn.), and bluegrass (Poa spp) plants were represented mostly by inflorescences that over-estimated their contribution to available forage. Grazing heights became shorter as the trial progressed and snow cover persisted while the proportion of grazed plants increased (Table 6). Variation among surveys, in the estimate of grazed plants, was influenced by the ability of the observer to detect grazing and by

Table 3. Average percent utilization over 3 consective years of important forage species on the fescue prairie in paddocks grazed by cattle in winter (supplemented with different rates of canola meal) or summer.

\begin{tabular}{|c|c|c|c|c|c|c|}
\hline Season & Supplement & $\begin{array}{c}\text { Parry } \\
\text { oatgrass }\end{array}$ & $\begin{array}{l}\text { Idaho } \\
\text { fescue }\end{array}$ & $\begin{array}{l}\text { Rough } \\
\text { fescue }\end{array}$ & $\begin{array}{l}\text { Smooth } \\
\text { aster }\end{array}$ & \\
\hline & $\left(\mathrm{kg} \mathrm{day}^{-1}\right)$ & $\ldots \ldots$ & $\cdots--($ & 1) $\ldots .$. & $\ldots \ldots$ & $\operatorname{LSD}(P=0.05)$ \\
\hline \multirow[t]{5}{*}{ Winter } & Mean & 10 & 5 & 36 & 1 & 9 \\
\hline & 1.2 & 8 & 2 & 34 & 0 & \\
\hline & 0.8 & 7 & 6 & 29 & 1 & \\
\hline & 0.4 & 14 & 9 & 45 & 1 & \\
\hline & 0.0 & 10 & 1 & 35 & 3 & \\
\hline Summer: & 0.0 & 48 & 14 & 62 & 14 & \\
\hline Summer/Winter & Mean & 29 & 8 & 48 & 9 & 19 \\
\hline
\end{tabular}

(no suppl.)

'LSD's were calculated only for significant $(\mathrm{P}<0.05)$ factors as determined by ANOVA's of canola supplementation effect in winter and of the seasonal ( summer vs winter with no supplements) effects. 
Table 4. Relative preferences for important forage species on the fescue prairie in paddocks grazed by cattle in winter (supplemented with different rates of canola meal) and summer over 3 consecutive years.

\begin{tabular}{|c|c|c|c|c|}
\hline & $\begin{array}{c}\text { Parry } \\
\text { oatgrass }\end{array}$ & $\begin{array}{l}\text { Idaho } \\
\text { fescue }\end{array}$ & $\begin{array}{l}\text { Rough } \\
\text { fescue }\end{array}$ & $\begin{array}{l}\text { Smooth } \\
\text { aster }\end{array}$ \\
\hline \multicolumn{5}{|c|}{ - (relative preference index) } \\
\hline 1992 & 0.25 & 0.29 & 1.47 & 0.0 \\
\hline 1993 & 0.36 & 0.07 & 1.57 & 0.0 \\
\hline 1994 & 0.56 & 0.23 & 1.22 & 0.28 \\
\hline Mean & 0.39 & 0.20 & 1.42 & 0.09 \\
\hline \multicolumn{5}{|c|}{$\operatorname{LSD}^{3}(P=0.05):$ species effects $=0.43 ;$ species $x$ year effects $=0.31$} \\
\hline Winter ${ }^{2}$ & 0.38 & 0.03 & 1.17 & 0.08 \\
\hline Summer & 0.98 & 0.35 & 1.28 & 0.33 \\
\hline \multicolumn{5}{|c|}{$\operatorname{LSD}^{3}(P=0.05)$ : species $x$ season effects $=0.26$} \\
\hline
\end{tabular}

Canola supplementation treatments pooled.

${ }^{2}$ No canola supplements

${ }^{3}$ LSD's were calculated only for significant $(P<0.05)$ factors as determined by ANOVA's of canola supplementation effect in winter and of the seasonal ( summer vs winter with no supplements) effects.

plant exposure that varied with new precipitation and redistribution of snow by wind. Cows were so observed to crater through snow for rough fescue plants. These plants were often heavily grazed, apparently to prehend fall regrowth near the crown or forbs (mostly Geum triflorum Pursh.) around the plant base.

\section{Discussion}

Cattle seemed to select plants that had the greatest available biomass, regardless of the level of supplementation with canola meal up to $1.2 \mathrm{~kg} \mathrm{day}^{-1}$. Rough fescue produced the greatest standing crop biomass and was the most highly preferred forage species in both winter and summer. Preferences for the shorter grass species, Parry oat grass and Idaho fescue, decreased from summer to winter presumably in response to reduced accessibility with snow cover. Supplementing cattle with canola meal had no effect on their forage selection as measured by indices of relative preference.

The presence of snow affected preferences for forage species by altering their accessibility to cattle and shifting the grazing pressure towards rough fescue. Snow formed a dome over rough fescue plants that cattle targeted for cratering. Also, wind redistributed the snow, usually exposing the rough fescue plants and accumulating between them, thereby covering plants of other species. This is illustrated with increasing preferences for Parry oat grass and Idaho fescue from 1992 to 1994 (Table 4) as snow
Table 5. Percent frequency distribution of rough fescue and Parry oat grass plants among utilization classes in winter ( no supplementation) and summer for 3 consecutive years 1 .

\begin{tabular}{|c|c|c|c|c|}
\hline \multirow[b]{2}{*}{ Utilization } & \multicolumn{2}{|c|}{ Rough fescue } & \multicolumn{2}{|c|}{ Parry oat grass } \\
\hline & Winter & Summer & Winter & Summer \\
\hline$(\%)$ & $\ldots$. & $\ldots$ & $\ldots$ & $\ldots$ \\
\hline 0 & 38.3 & 29.2 & 78.5 & 36.4 \\
\hline$>0-25$ & 9.7 & 6.4 & 4.2 & 5.6 \\
\hline$>25-50$ & 16.6 & 8.0 & 7.2 & 9.7 \\
\hline$>50-75$ & 33.5 & 19.5 & 8.2 & 16.6 \\
\hline$>75$ & 1.8 & 36.9 & 1.8 & 31.7 \\
\hline Number $^{2}$ & 502 & 659 & 592 & 1496 \\
\hline
\end{tabular}

${ }^{1}$ Within species, frequency distribution between seasons was significantly different $(P>$ 0.01 ) using the Chi-square test.

${ }^{2}$ Total number of plants represented in each data set.

conditions became less severe (Table 1) and from winter to summer as accessibility became strictly a function of standing crop.

The high preference for rough fescue in summer was unexpected. In a previous study, ungrazed forage patches dominated by rough fescue (Willms et al. 1988) seemed to indicate an avoidance in summer and suggested the possibility of developing a grazing system based on seasonal selection differences. Results from the present study, however, indicate that patch avoidance was not the result of the presence of rough fescue plants but rather the result of accumulated litter

Forage preference is at least partly a function of the kind of animal (Heady 1964) and differences in their selectivity and ability to prehend forage. Grazing efficiency would be maximized by the generalist herbivore by selecting the larger rough fescue plants either in winter or summer. This grazing strategy, and the nutritive similarity among species, would also negate the effects of CP supplements on species selection in winter

Reduced forage digestibilities from summer to winter resulted in reduced intake and subsequently reduced grazing pressure at similar stocking rates. Heavier grazing pressure in summer $(49 \%)$ compared with winter $(29 \%)$ increased the proportion of plants that were heavily grazed and reduced the number that were lightly grazed (Table 5) and resulted in different patterns of use among rough fescue plants and among Parry oat grass plants.

Winter conditions seemed to mitigate against very heavy (>75\%) utilization among rough fescue plants and most utilization among Parry oat grass plants. The bimodal frequency distribution of use of rough fescue plants in winter suggests that cattle will graze the same plant heavily rather than search for another in the snow. This phe-

Table 6. Snow conditions and foraging characteristics by cattle on the fescue grasslands in winter (1992-93) $(n=84)$

\begin{tabular}{|c|c|c|c|c|c|c|c|c|c|c|c|c|c|}
\hline \multirow[b]{2}{*}{ Date } & \multicolumn{2}{|c|}{ Snow } & \multirow{2}{*}{$\begin{array}{l}\text { Plant } \\
\text { height }\end{array}$} & \multicolumn{2}{|c|}{ Grazed plants } & \multirow{2}{*}{$\begin{array}{l}\text { Grazed } \\
\text { plots }^{1}\end{array}$} & \multirow{2}{*}{$\begin{array}{l}\text { Wheat } \\
\text { grass }\end{array}$} & \multirow[b]{2}{*}{ Timothy } & \multirow[b]{2}{*}{ Brome } & \multirow{2}{*}{$\begin{array}{c}\text { Parry } \\
\text { oat grass }\end{array}$} & \multirow{2}{*}{$\begin{array}{l}\text { Idaho } \\
\text { fescue }\end{array}$} & \multirow{2}{*}{$\begin{array}{l}\text { Rough } \\
\text { fescue }\end{array}$} & \multirow[b]{2}{*}{ Bluegrass } \\
\hline & Depth & Cover & & height & area & & & & & & & & \\
\hline & $(\mathrm{cm})$ & $(\%)$ & $(\mathrm{cm})$ & $(\mathrm{cm})$ & $\left(\%^{2}\right)$ & $\ldots$. & $-\cdots$ & $-\cdots(\%$ & of grazed & (hots) $\ldots$ & 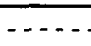 & $\ldots$ & \\
\hline Nov. 25 & 9 & - & 34 & 15 & 4 & 39 & 15 & 8 & 2 & 5 & 8 & 90 & 21 \\
\hline Dec. 2 & - & 50 & 10 & 6 & 16 & 58 & 22 & 9 & 3 & 12 & 16 & 100 & 28 \\
\hline Dec. 9 & 6 & 19 & 10 & 6 & 14 & 46 & 32 & 4 & 2 & 20 & 6 & 89 & 37 \\
\hline Dec. 15 & 4 & 44 & 10 & 8 & 17 & 77 & 11 & 3 & 6 & 28 & 12 & 98 & 29 \\
\hline Dec. 21 & 7 & 91 & 13 & 11 & 28 & 72 & 8 & 7 & 12 & 43 & 11 & 97 & 8 \\
\hline Jan. 7 & 15 & 92 & 18 & 2 & 31 & 40 & 0 & 0 & 2 & 40 & 2 & 92 & 2 \\
\hline Jan. 18 & 13 & 93 & 13 & 3 & 24 & 34 & 3 & 3 & 3 & 44 & 0 & 97 & 3 \\
\hline
\end{tabular}

Number of plots where grazing was evident ( $n=84)$

2Proportion of exposed plant area showing evidence of grazing. 
nomenon was observed in the first winter when feeding surveys were made. In summer, this effect is likely produced from regrazing regrowth and avoiding previously ungrazed plants.

\section{Management Implication}

The opportunities for winter grazing by livestock are directly related to the proportion of rough fescue in the plant community and, therefore, correspond to the condition of the fescue grasslands. Rough fescue grasslands seem capable of sustained summer grazing at 2.4 animal unit months $\mathrm{ha}^{-1}$ which reduced the proportion of rough fescue to about $20 \%$ of the species composition (Willms et al. 1985). However, the resulting community lost most of its value for winter grazing and, presumably, for large wildlife herbivores such as elk (Cervus canadensis nelsoni Nelsoni) which depend on grass for their winter forage (Mackie 1965, Beall 1974). Plants grazed heavily during the dormant season may also have reduced availability after the next growing season due to shortened leaves (Willms et al. 1986). Therefore, it is not only important to maintain rough fescue in the community but also to ensure that a significant proportion of plants escape heavy grazing. While stocking at 2.4 animal-unit-months ha-1 in summer asserts too much grazing pressure, stocking at 3.2 animalunit-months ha-1 seems suitable for winter grazing and appears to offer an opportunity to reduce the cost of winter feeding.

\section{Literature Cited}

Beall, R.C. 1974. Winter habitat selection and use by a western Montana elk herd. Ph.D. Thesis, Univ. Montana. Missoula, Mont.

Bezeau, L.M. and A. Johnston. 1962. In vitro digestibility of range forage plants of the Festuca scabrella association. Can. J. Plant Sci. 42: 692-697.

DelCurto, T., R.C. Cochran, L.R. Corah, A.A. Beharka, E.S. Vanzant, and D.E. Johnson. 1990. Supplementation of dormant tallgrass-prairie forage: II. Performance and forage utilization characteristics in grazing beef cattle receiving supplements of different protein concentrations. J. Anim. Sci. 68: 532-542.

Heady, H.F. 1964. Palatability of herbage and animal preference. J. Range Manage. 17: 76-82.

Johnston, A. and L.M. Bezeau. 1962. Chemical composition of range forage plants of the Festuca scabrella association. Can. J. Plant Sci. 42: $105-115$.

Kreuger, W.C. 1972. Evaluating animal forage preference. J. Range Manage. 25: 471-475.

Mackie, R.J. 1965. Range ecology and relations of mule deer, elk, and cattle in the Missouri River breaks, Montana. Ph. D. Thesis. Montana State Univ. Bozeman, Mont.

Provenza, F.D. 1995. Postingestive feedhack as an elementary determinant of food preference and intake in ruminants. J. Range Manage. 48:2-17.

Steel, R.G.D. and J.H. Torrie. 1980. Principles and procedures of statistics: A biometrical approach. McGraw Hill Book Co., New York, N.Y.

Stout, D.G., A. McLean, and D.E. Quinton. 1981. Growth and phenological development of rough fescue in the interior of British Columbia. J. Range Manage. 34:455-459.

Westoby, M. 1974. An analysis of diet selection by large generalist herbivores. The Amer. Nat. 108: 290-304.

Willms, W. D. 1988. Forage production and utilization in various topographic zones of the fescue grasslands. Can J. Anim. Sci. 68:21 1-223.

Willms, W., A.W. Bailey, and A. McLean. 1980. Effect of fall burning or fall clipping bluebunch wheatgrass (Agropyron spicatum) on the spring foraging behavior of mule deer (Odocoileus hemionus hemionus) and cattle. J. Appl. Ecol. 17: 69-84.

Willms W. D., J.F. Dormaar, and G.B. Schaalje. 1988. Stability of grazed patches on rough fescue grasslands J. Range Manage. 41:503-508.
Willms, W.D., S. Smoliak, and J.F. Dormaar. 1985. Effects of stocking rate on rough fescue grassland vegetation. J. Range Manage. 38:220-225.

Willms, W.D., S. Smoliak, and A.W. Bailey. 1986. Herbage production following litter removal on Alberta native grasslands. J. Range Manage. 39:536-539.

Wroe, R.A., S. Smoliak, B.W. Adams, W.D. Willms, and M.L. Anderson. 1988. Guide to range condition and stocking rates for Alberta grasslands 1988. Publ. of Alberta Forestry, Lands, and Wildlife, Edmonton, Alberta.

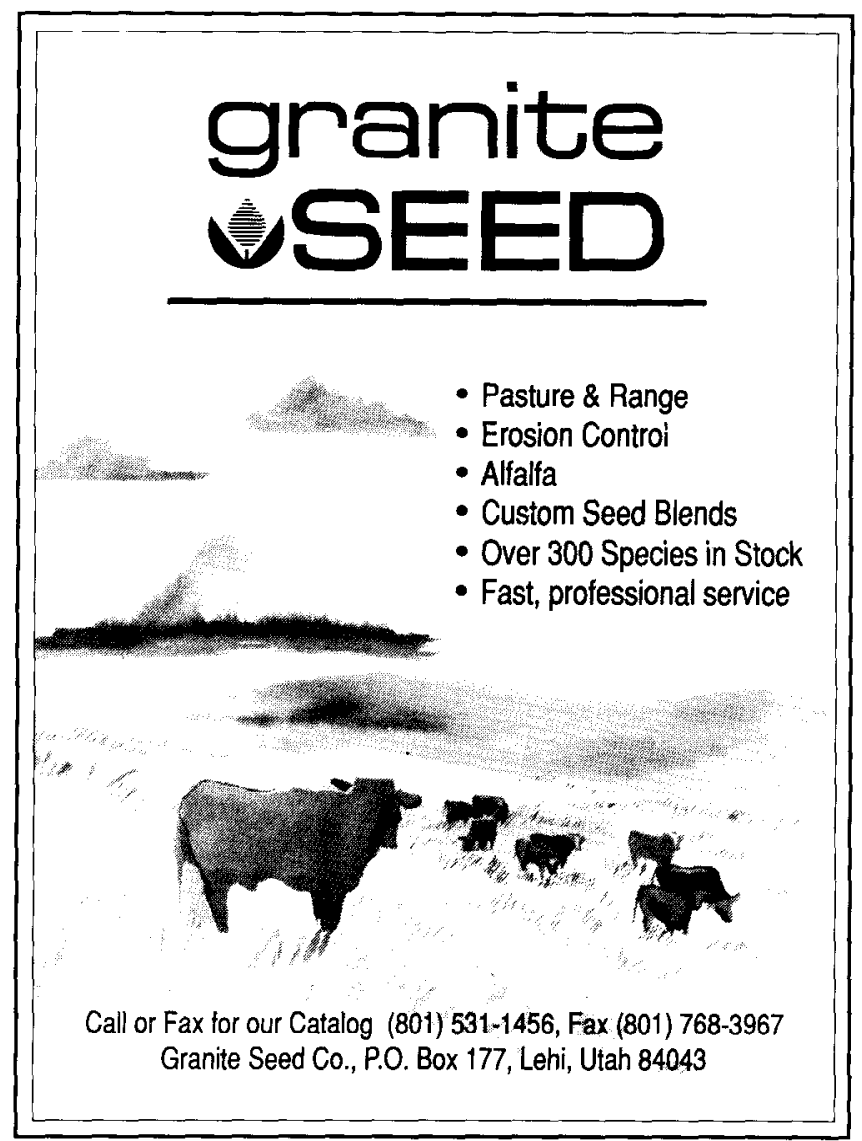

